\title{
IRON ORE ON CANYON CREEK, FORT APACHE INDIAN RESERVATION, ARIZONA
}

\author{
By Ernest F. Burchard
}

\section{INTRODUCTION}

Reported deposits of iron ore in the western part of the Fort Apache Indian Reservation, Ariz. (fig. 6), were examined by B. W. Dyer, mining engineer, and E. F. Burchard, geologist, of the United States Geological Survey, from May 31 to June 17, 1929. The primary purpose of the investigation was to get the facts concerning the deposits, so that the best interests of the Indian owners might be kept in view in setting the terms of any lease that might be issued thereon. Mr. Dyer has contributed to the present paper a section on conditions affecting mining development of certain deposits.

As the deposits are remote from habitations of white men temporary camps were necessary at two localities. Robert Hinton was employed as rodman and Jack Hatcher as cook. The party was outfitted at the Indian agency at Whiteriver, and the courteous assistance of William Donner, superintendent, and other officers of the agency at Whiteriver and at Cibecue is hereby gratefully acknowledged. It was possible to go by automobile to a point about 6 miles west of Grasshopper and about 8 miles from the principal deposits of iron ore, but the final stage of the trip had to be made by pack train. The distance to the ore deposits from Whiteriver by this route is about 75 miles, but in an air line west-northwest it is only about 50 miles.

\section{LOCATION AND ACCESSIBILITY}

The iron-ore deposits here described consist of two groups along Canyon Creek 2 to 3 miles east of the west border of the Fort Apache Reservation and 7 and 12 miles south of the north border. The principal deposits examined are on claims known as the AlsaceLorraine group, on the east and west sides of Canyon Creek just south of the mouth of Bear Spring Canyon (fig. 7), and the others were 4 or 5 miles farther south, on the left side of Canyon Creek 
half a mile to a mile below Lost Tanks Gulch and on Chediski Mountain opposite and below the mouth of Willow Creek (fig. 9). No land surveys have been made in the areas containing the deposits, and there are no maps available that show the drainage accurately.

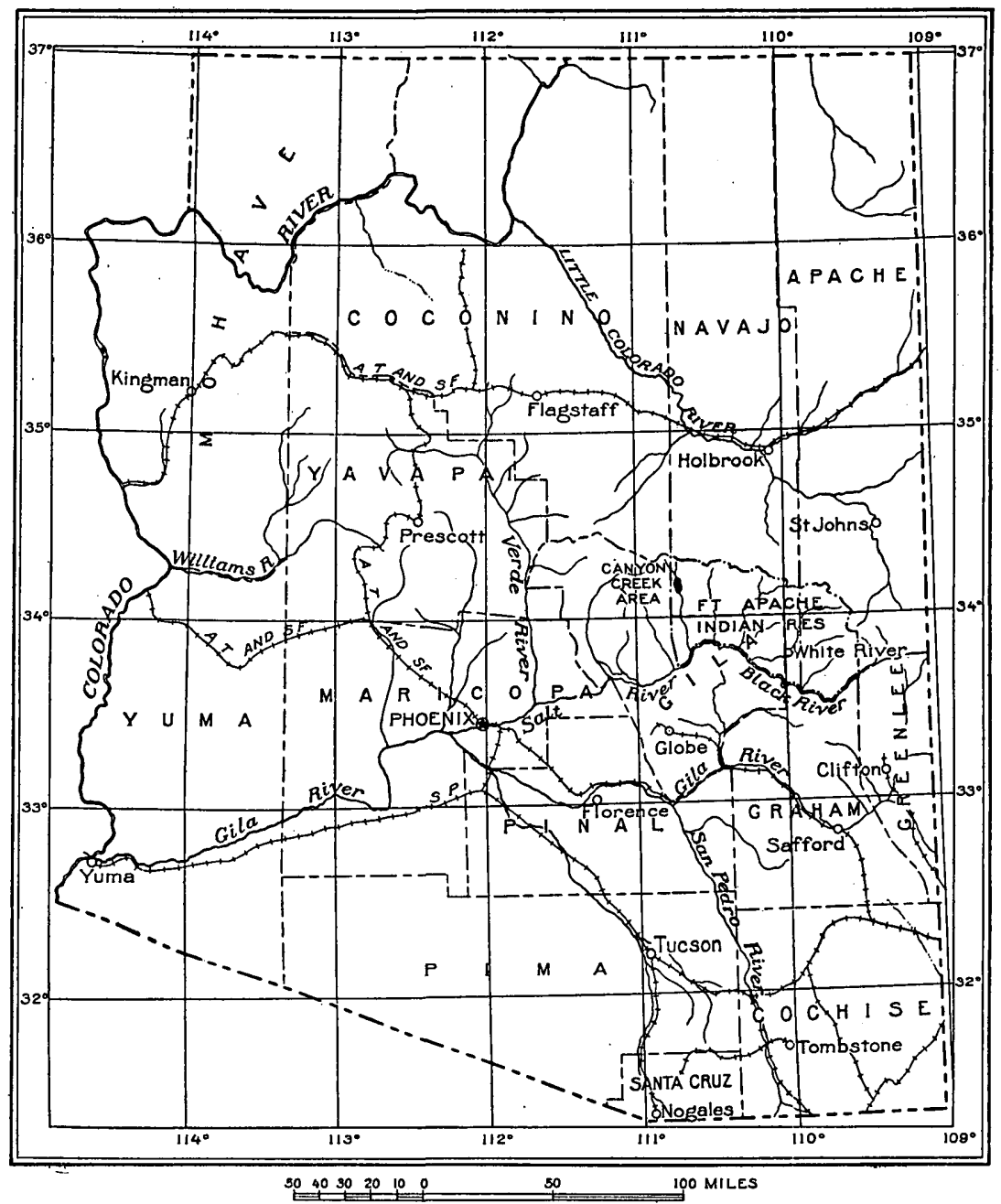

Frgure 6.-Index map showing location of iron-ore area on Canyon Creek, Ariz.

As well as can be ascertained from the fire-control map of the Fort Apache Indian Reservation, issued by the Indian Service, the deposits examined are all within T. 9 N., R. 151/2 E.

The deposits are not at present accessible by vehicle, but a logging railroad that connects with the Atchison, Topeka \& Santa Fe Railway at Holbrook reaches a place named Standard, approximately in the northeast corner of T. 10 N., R. 19 E., about 26 miles in an 
air line east-northeast of the principal Canyon Creek iron area but about 40 miles distant along the divide. As there is considerable good timber near Canyon Creek the railroad might possibly be continued to that locality to carry both timber and ore if these resources should prove to be commercially valuable.

\section{GEOGRAPHY}

The Fort Apache Indian Reservation is in east-central Arizona on the south slope of the Mogollon Plateau, in the Salt River drainage basin. The northwestern part of the reservation, where the deposits of iron ore are situated, is drained by Canyon Creek, one of the northern tributaries of the Salt River. Canyon Creek has a moderate flow throughout the dry season, but at the time of melting snows and heavy rains it becomes a good-sized river and often overflows its boulder-strewn channel, which is 200 to 300 feet wide. To judge by the logs that have been washed high on the bottom lands of the Chediski Indian Farms, near the mouth of Willow Creek, the stream becomes greatly swollen at times. In the upper part of its course Canyon Creek has few tributary streams that carried water at the time of visit; Bear Spring Canyon and Miners Gulch had spring water in places, and Willow Creek was fed by springs of alkaline water. Oak Creek, farther south, is a larger tributary.

The Mogollon Plateau attains an altitude of more than 7,500 feet above sea level near the head of Canyon Creek, according to the topographic map of Arizona. On the south slope of the plateau are many salients, between which are streams that cut their channels steeply toward the Salt River, which flows westward 30 to 40 miles south of the divide. The altitude along the Salt River near the mouth of Canyon Creek is about 2,350 feet, which would indicate a fall of 5,200 feet for Canyon Creek in a distance of 35 miles, or about 150 feet to the mile, if it had a fairly straight course, but its actual length is greater because the stream is sinuous in places. The salients that extend southward from the Mogollon Plateau maintain a high altitude for several miles and show remnants of a former terrace a few hundred feet below the crest. The Chediski lookout ranger station is on one of these salients, where a wide view is afforded for forest fires. The canyons of the larger streams are mostly deep and steep walled. Canyon Creek between Willow Creek and Bear Spring Canyon flows at altitudes of 5,500 to 5,800 feet, and the bordering ridges and knobs on the east and west of the creek reach altitudes 1,000 feet greater. The country is rough and fairly well wooded. Yellow pine predominates, but there are other varieties of pine, as well as juniper, cedar, oak, and cottonwood. Under- 
brush is so thick on the lower slopes as to render mapping with plane table and stadia slow and difficult.

'The following maps showing general features of this portion of Arizona are available:

Topographic map of Arizona, scale 1:500,000. Arizona Bureau of Mines, in cooperation with United States Geological Survey.

Geologic map of Arizona, scale 1:500,000. Arizona Bureau of Mines, in cooperation with United States Geological Survey.

Reconnaissance topographic map of Holbrook quadrangle (1 degree), scale 1:250,000. United States Geological Survey.

State of Arizona, scale 1 inch equals 24 miles. United States Department of the Interior.

Fort Apache Indian Reservation, Ariz., fire-control map, scale 1 inch equals 4 miles. United States Indian Service.

None of these maps accurately or adequately depict the local geographic features, such as drainage and mountains, and many of the names that are used in succeeding portions of this text do not appear on any map but have been adopted from local usage. There are, however, certain names in local use for which official sanction seems appropriate. For instance, opposite the mouth of Willow Creek (fig. 9) stands a prominent even-topped ridge about 1 mile in length and rising abruptly to a height of more than 1,000 feet above Canyon Creek, which is called by the Apache Indians "Chediski Mountain." (See pl. 14, A.) The word "chediski" as used by the Apaches means a "long white rock," or a " face of white rock extending for a considerable distance." 1 The name evidently has been applied to this mountain because of the bed of white sandstone that forms a cliff on the northeast face of the mountain and is conspicuous for many miles. This sandstone itself is a conspicuous member of the local rock formations, is widespread in the Canyon Creek area, and is named the Chediski white sandstone member of the Troy quartzite from the type locality of its occurrence. (See pl. $14, \dot{A}, B$.)

The high ridge on the east side of Canyon Creek in the vicinity of the Alsace-Lorraine iron-ore claims is locally called Swamp Creek Mountain. Willow Creek; Bear Spring Canyon, and Miners Gulch are also strictly local names.

About 1 mile below Bear Spring Canyon (locality 13, fig. 7) Canyon Creek has intrenched itself in an S-shaped gorge cut in horizontally bedded quartzite. A narrow ridge of this quartzite between meanders of the stream has been reduced by erosion and weathering to a row of towerlike crags many of which are separated from one another by spaces developed along vertical joints. (See pl. 16, A.)

${ }^{1}$ Letter from William Donner, superintendent, Fort Apache Indian Reservation, Oct. 31, 1929. 
In the location notices of the Alsace-Lorraine iron-ore claims these crags are referred to as The Pyramids, and that term is therefore employed in this paper, although better descriptive terms would be "towers" or " pillars."

\section{GEOLOGY}

The rocks exposed along Canyon Creek in the vicinity of the ironore deposits are sediments of the Apache group, considered by some geologists to be of pre-Cambrian age and by others to be of Cambrian (?) age. Diabase laccoliths have been intruded into the Apache rocks, notably near the Mescal horizon, and Devonian and Carboniferous sediments overlie the Apache rocks unconformably.

The following section ${ }^{2}$ indicates the general stratigraphic sequence of the formations in central Arizona:

Formations of the Apache group in central Arizona

[After Ransome]

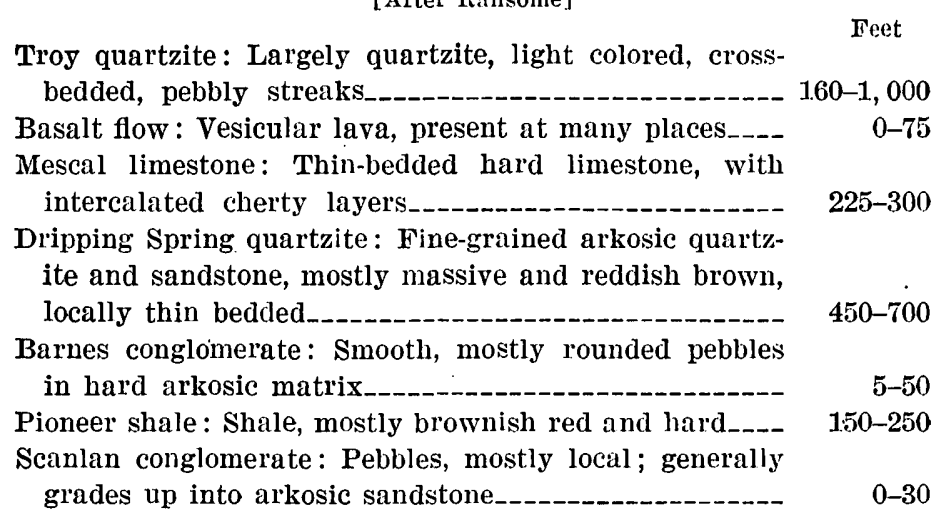

Darton notes that these formations, especially the lower ones, are generally invaded by thick sills of diabase. Ransome found the Apache group extensively exposed in the vicinity of Globe and Ray, and Darton traced these rocks northward up Canyon Creek and Cherry Creek across the headwaters of the Verde River to the base of the Mogollon Plateau. The Apache rocks are generally overlain by the Martin limestone, of Devonian age.

In the locality here described there is not, as indicated in the generalized geologic section by Ransome shown above, a vesicular lava, or basalt flow, overlying the Mescal limestone. The Mescal locally contains no limestone, so far as observed, and was identified only as a thin zone of banded chert, generally more or less ferruginous, in many places sufficiently so to constitute an ore of iron.

2 Darton, N. H., Résumé of Arizona geology : Arizona Univ. Bull. 119, p. 27, 1925. 
A generalized geologic section of the rocks exposed along Canyon Creek in the vicinity of Bear Spring Canyon is as follows:

Section of rocks along Canyon Creek near Bear Spring Canyon

Martin (?) limestone: Limestone, fossiliferous, cherry in places; top probably eroded.

Feet

roy quartzite:

Quartzite, light gray to light brown, medium to massive beds

White sandstone, fine to medium grain, with white sericitic interstitial cement (Chediski white sandstone member)

$50-100$

Mescal limestone:

Banded chert, ferruginous in places; merges downward into iron ore

Iron ore (hematite), more or less cherty; merges upward into banded chert

Dripping Spring quartzite: Quartzite, light buff to reddish, thin to medium bedded

$125-200$

Diabase laccolith, intruded into overlying quartzite

400

Canyon Creek.

A similar section is exhibited by the rocks along Canyon Creek in the Willow Creek-Chediski Mountain locality, except that the diabase does not appear at the base and there are beds of quartzite that are lower than those indicated above.

Thin sections of the igneous rock from Canyon Creek in the vicinity of Bear Spring Canyon were examined by C. S. Ross, of the United States Geological Survey. A specimen of rather fresh material from a point a little less than 1 mile above Bear Spring Canyon was pronounced "typical diabase, probably sill-like but possibly a deep-seated intrusive," and one of partly weathered material obtained about 1,000 feet below the mouth of Bear Spring Canyon "rock of diabase habit, much altered; augite has become hornblende."

The diabase is exposed along Canyon Creek from a point about 1,000 feet below the mouth of Bear Spring Canyon to and beyond the point where the field traverse was discontinued at the north, about $11 / 2$ miles above the mouth of that canyon. The complete area of diabase is shown on the geologic map of Arizona to have a linear extent of about $2 \frac{1}{2}$ miles and a width of less than 1 mile. The intrusion produced in the overlying sedimentary rocks an anticline with its axis plunging southward below Canyon Creek, as is illustrated by the trace of the outcrop of the bed of iron ore. (See figs. 7 and 8.) No actual contact between the diabase and the overlying quartzite was observed, but in several places quartzite that is within a very few feet of this contact is exposed, and it shows little or no metamorphism. The highest point above Canyon Creek at which the diabase was observed was in Miners Gulch about half a mile northeast of 


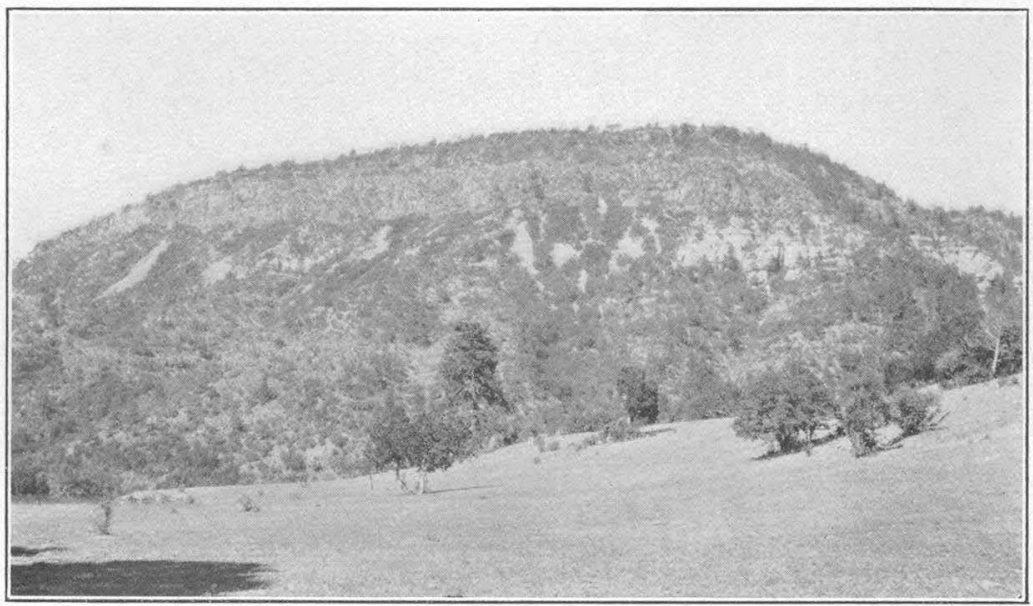

A. CHEDISKI MOUNTAIN, ON RIGHT BANK OF CANYON CREEK OPPOSITE MOUTH OF WILLOW CREEK, ARIZ

The light-colored rock on the mountain side is the Chediski white sandstone member of the Troy quartzite.

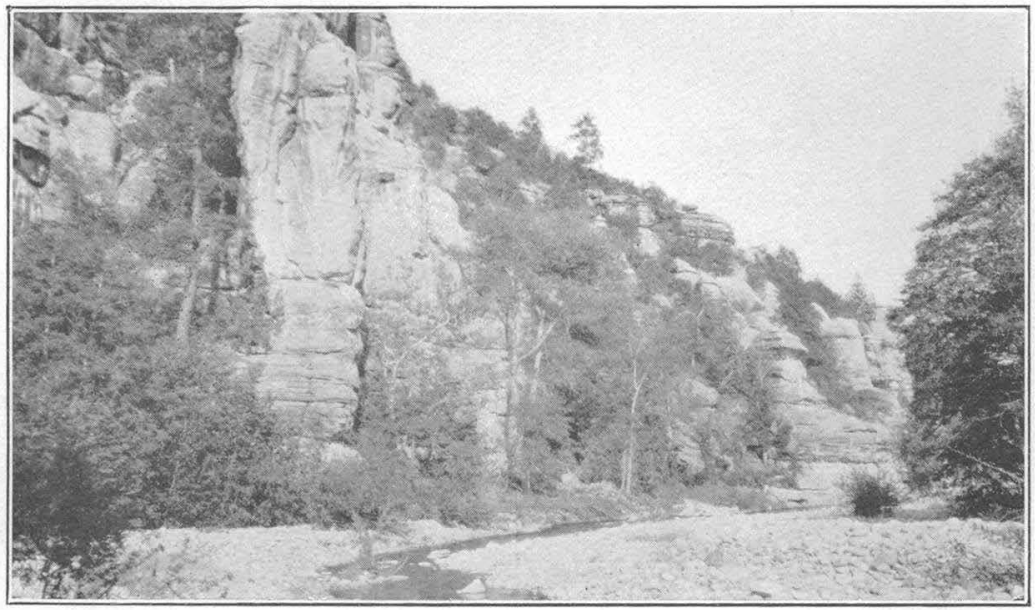

B. CLIFFS FORMED BY CHEDISKI WHITE SANDSTONE MEMBER OF TROY QUARTZITE ON LEFT BANK OF CANYON CREEK, OPPOSITE CHEDISKI MOUNTAIN 


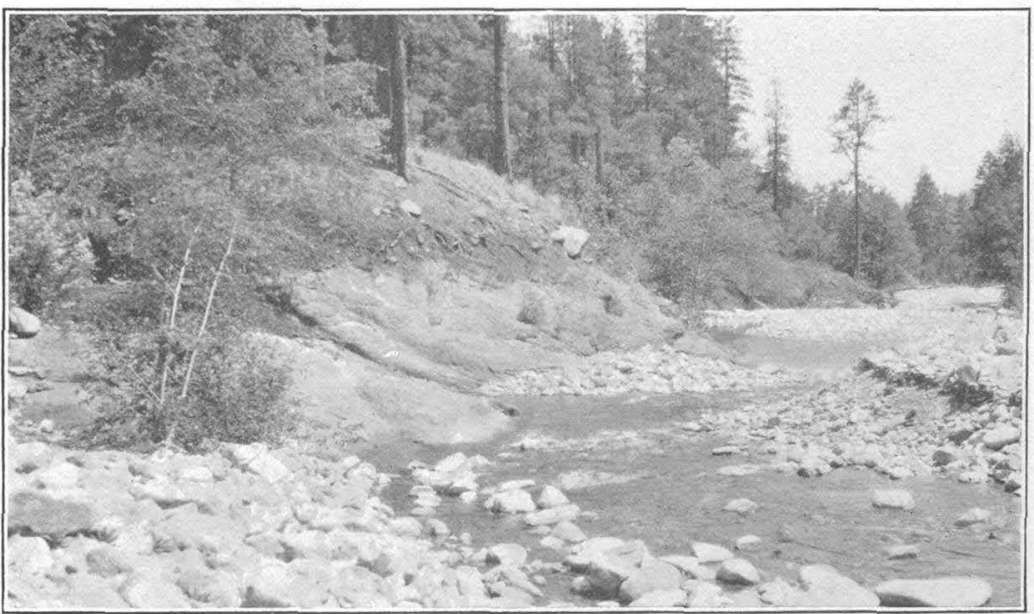

A. CANYON CREEK AT MOUTH OF MINERS GULCH

Weathered diabase forms left bauk of stream.

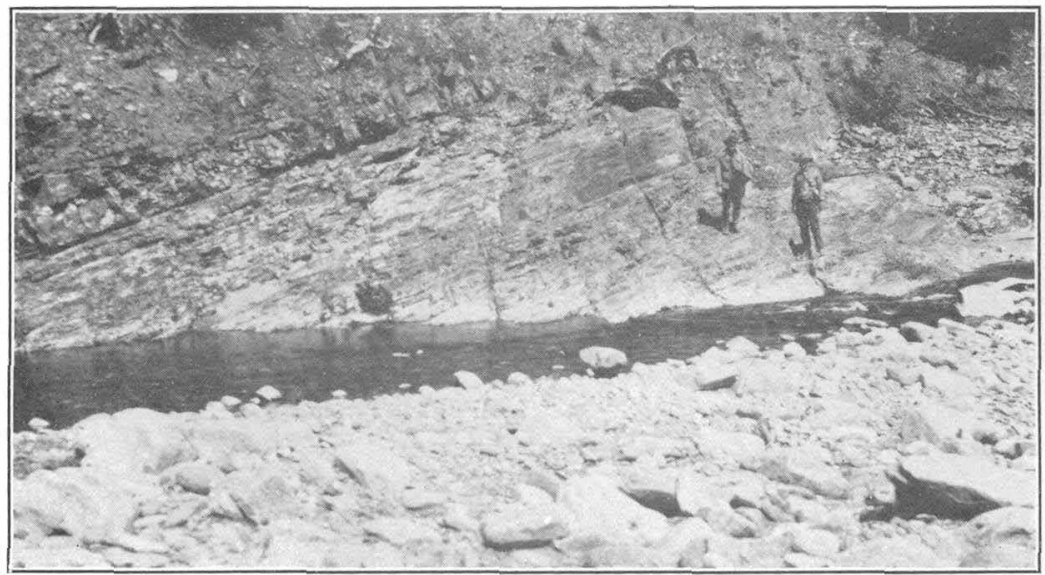

B. DRIPPING SPRING QUARTZITE ON RIGHT BANK OF CANYON CREEK BELOW BEAR SPRING CANYON

Dip of beds is due to laccolith of diabase a short distance beneath. 


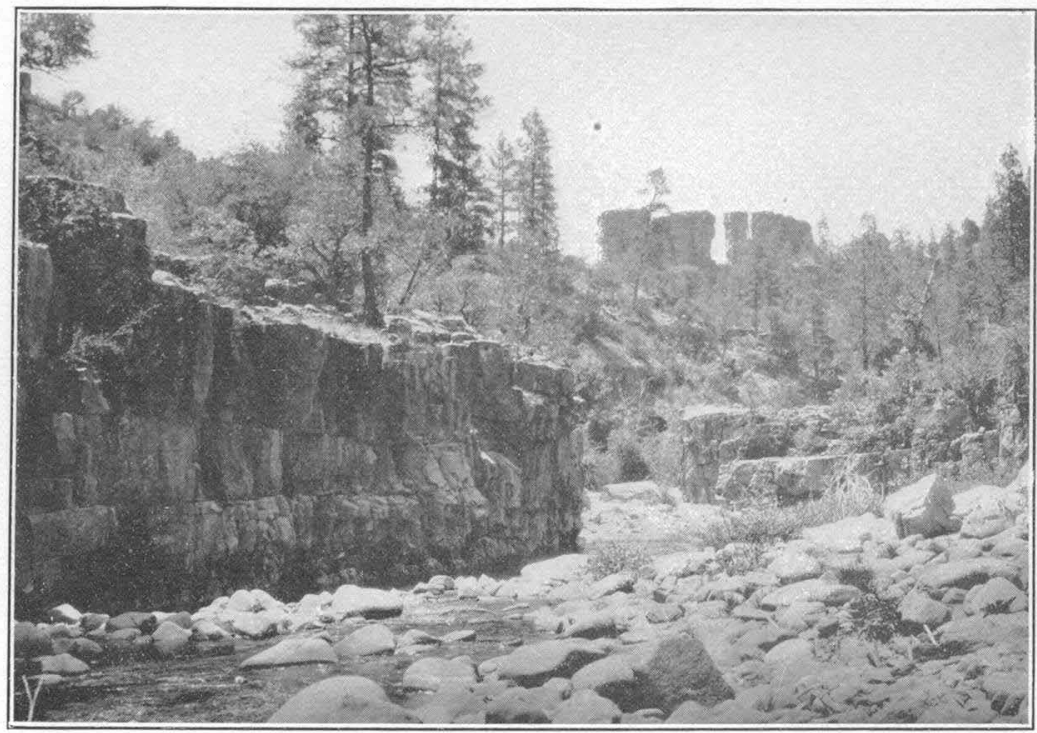

A. THE PYRAMIDS, CANYON CREEK

The Pyramids are the flat-topped towers in the distance, formed by the Troy quartzite. Beds of similar quartzite appear in the foreground.

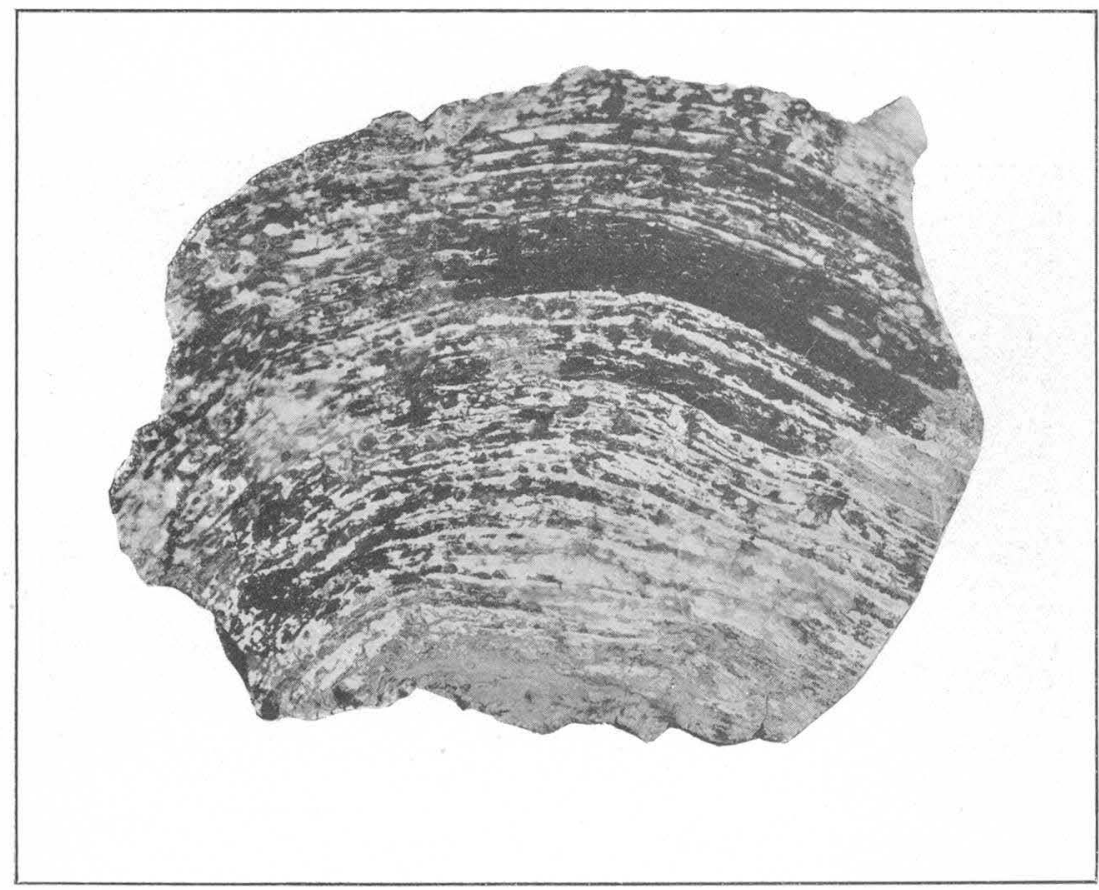

B. POLISHED SURFACE OF BANDED CHERT PARTLY REPLACED BY IRON OXIDE

From locality 2, Canyon Creek. Light bands are opaline silica; gray areas, hematite; dark areas, silica stained red by hematite. Natural size. 


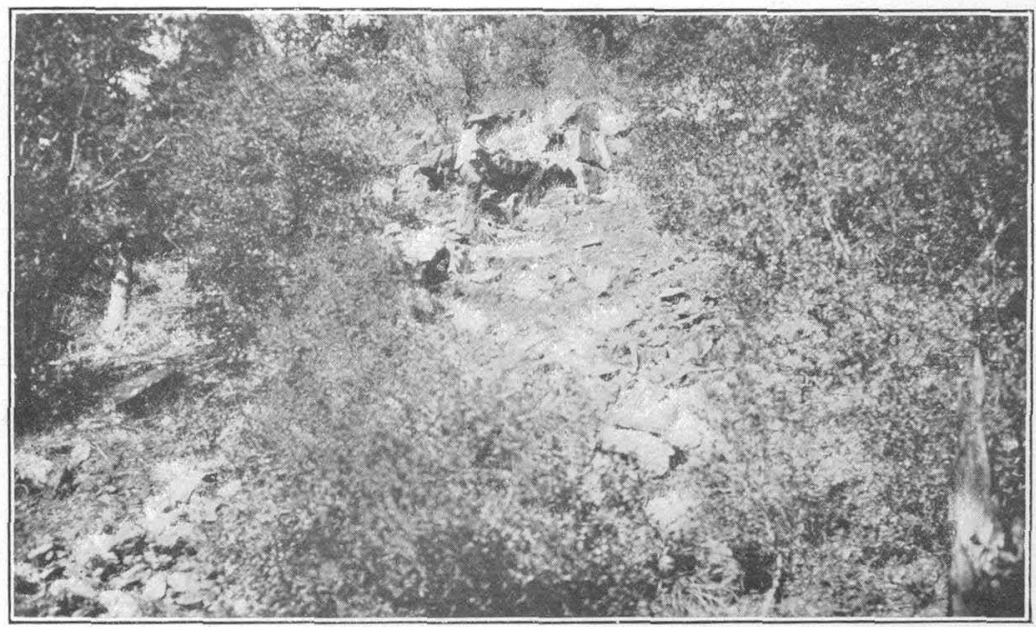

A. PROSPECT IN BED OF IRON ORE ON STEEP HILLSIDE AT LOCALITY 2

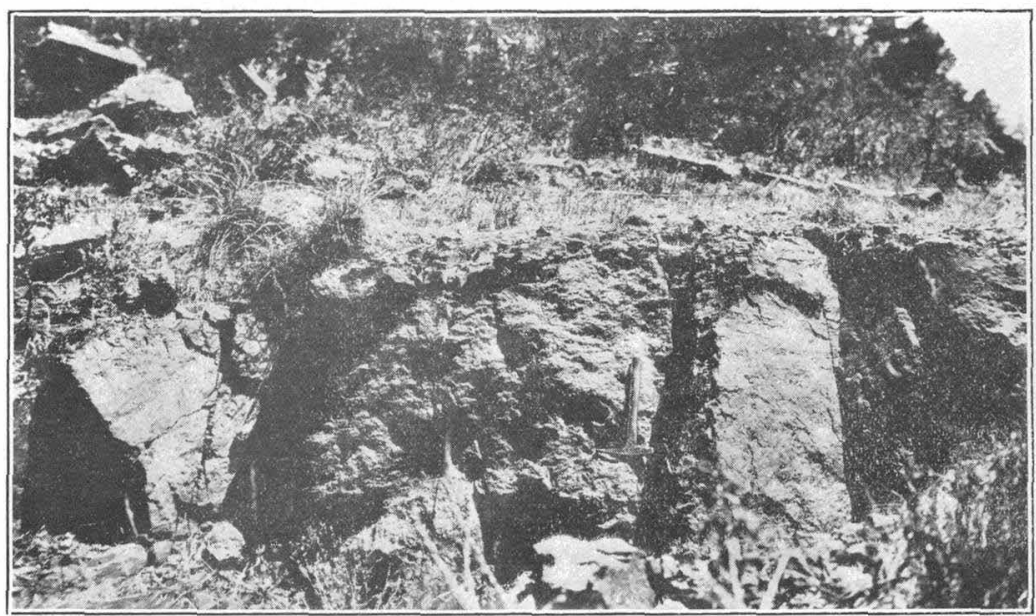

$B$. PROSPECT IN BED OF IRON ORE AT LOCALITY 4 


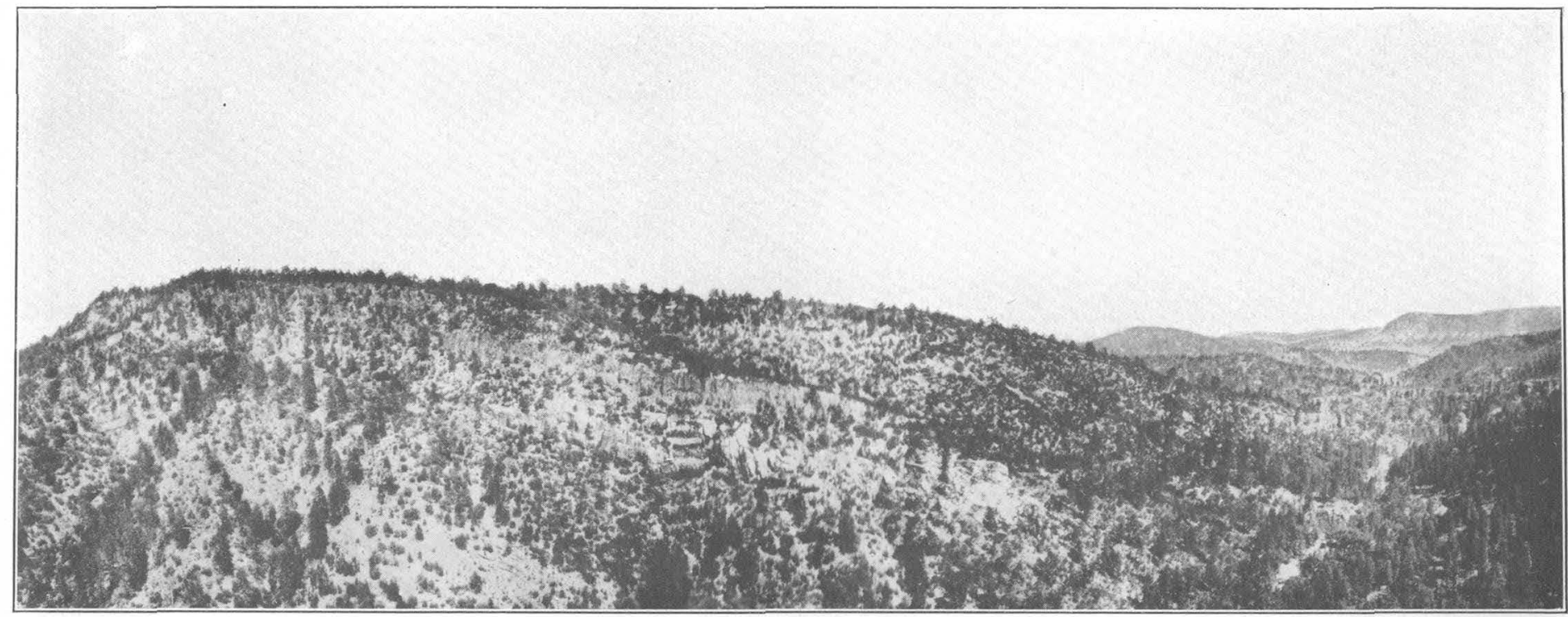

PANORAMA FROM WEST SIDE OF CANYON CREEK AT BEAR SPRING CANYON

At left, Swamp Creek Mountain, with Chediski white sandstone member overlying horizon of iron ore; at right, Canyon Creek, with The Pyramids in the middle distance and Chediski Mountain in the upper corner. 
Canyon Creek and about 400 feet higher. An uneven surface of the diabase is indicated here, for diabase boulders were observed in the gulch a short distance above the lowest exposure of quartzite. A short distance south of the contact of the diabase and quartzite on Canyon Creek the beds of quartzite are evenly tilted so that they dip about $22^{\circ}$. S. (pl. 15, B), but about 2,100 feet farther south on the east side of Canyon Creek, at locality 12 (fig. 7), a sharp flexure in the rocks is exposed, north of which the beds of quartzite dip $60^{\circ}-75^{\circ} \mathrm{S}$. and south of which they continue in nearly horizontal attitude to and beyond The Pyramids (figs. 7 and 8). In addition to the flexures in the rocks a few east-west faults were encountered in making traverses, but as no complete geologic map was prepared these faults were not followed. Two small faults offset the ore bed on the east side of Canyon Creek near localities 2 and 6, and a fault having considerable downthrow on its south side was noted south of Bear Spring Canyon about 1,100 feet S. $80^{\circ}$. W. of the ore outcrop at locality 11. Here a fossiliferous limestone, normally 300 to 400 feet higher in the section, is dropped down against the quartzite. In the vicinity of Chediski Mountain a northwesterly fault along Canyon Creek is indicated by the position of the bed of iron ore and the overlying white sandstone, which are high on the mountain on the southwest side of the creek and about at water level on the northeast side. (See fig. 9 and pl. $14, A, B$.)

The section of rocks exposed along Canyon Creek (p. 8) is sufficiently explicit for present purposes, but it is believed that the bed of white sericitic sandstone near the base of the Troy quartzite and above the iron-bearing portion of the Mescal limestone deserves more than passing notice. This bed is typically exposed on the northeast face of Chediski Mountain (pl. 14, A) and makes picturesque cliffs weathered vertically into semicolumnar forms on the northeast side of Canyon Creek above the mouth of Willow Creek (pl. 14, B). From the vicinity of Lost Tank Canyon northward for about 2 miles it is below the level of Canyon Creek, but it is brought to view about half a mile north of The Pyramids by the doming of the strata above the diabase laccolith and is visible up Canyon Creek for more than a mile. (See pl. 18 and fig. 8.) Because of its persistence in this region and its service as a conspicuous marker just above the horizon of iron ore, it is here proposed that this bed be known as the Chediski white sandstone member of the Troy quartzite.

\section{IRON ORE}

\section{ASSOCIATED ROCKS}

The iron ore is associated closely with beds of chert or "jasper" that have a concentrically curved and contorted banding resembling 
superficially fossil algae of the cryptozoan type. The ore seems to be a part of the chert beds and to grade into chert in all directions, but particularly within a short distance upward. Below the ore horizon the rock is thin to medium bedded quartzite, and from a few feet to 50 feet or more above the ore is the well-marked Chediski white sandstone described above. This white sandstone makes a conspicuous marker for the iron-ore horizon, and from high points it can be seen for a mile or more along Canyon Creek in the vicinity of Bear Spring Canyon and also on the east face of Chediski Mountain, about 5 miles distant. (See pls. 14, $A$, and 18.)

The stratigraphic position of the iron ore, according to Darton, ${ }^{3}$ is within the upper part of the Mescal limestone, which in this vicinity is "thin, highly siliceous [cherty], and in part locally replaced by iron ore." The white sandstone beds above the ore horizon are considered to belong to the Troy quartzite, and above the white sandstone lies massive quartzite. Above the Troy quartzite on the crest of Swamp Creek Mountain and at corresponding levels to the east and southeast is fossiliferous limestone, probably the Martin limestone, of Devonian age. Below the Mescal horizon the beds presumably represent the Dripping Spring quartzite, and in the vicinity of Bear Spring Canyon these beds have been intruded by a laccolith of diabase which tilts them up toward the north but has not produced conspicuous changes in the character of the beds near the contact.

\section{DISTRIBUTION}

The bed of iron ore was examined in two localities on Canyon Creek, in the vicinity of Willow Creek and Chediski Mountain and in the vicinity of Bear Spring Canyon. The ore bed has been prospected and several claims staked on the left bank of Canyon Creek between the mouths of Willow Creek and Lost Tank Gulch, also on the right side of the creek on the east face of Chediski Mountain at intervals from a point above the mouth of Willow Creek southward to Mountain Lion Canyon, a distance of about threequarters of a mile. (See fig. 9.) At the locality on Canyon Creek 4 to 5 miles above Willow Creek prospects have shown the outcrop. of the bed of iron ore to form a $\mathbf{V}$-shaped trace crossing the creek about 2,850 feet below the mouth of Bear Spring Canyon and extending up the valley of the creek for distances of about 2,500 feet toward the northwest and 6,000 feet toward the northeast, as indicated in Figure 7. Seven mining (lode) claims, known as the Alsace-Lorraine group, were first filed by R. L. Keith on land com-

Darton, N. H., op. cit., pp. 230, 237. 
prising this outcrop of the iron ore, and a survey (No. 3711) of these claims was made in 1920 by R. L. Merritt, of Prescott, Ariz., deputy mineral surveyor for the General Land Office. In $1922 \mathrm{Mr}$. Keith filed notices of Alsace-Lorraine claims 7, 8, and 9, lying east of and parallel to the Alsace-Lorraine and Alsace-Lorraine claims 1,2 , and 3.

\section{CHARACTER AND ORIGIN}

The iron ore is hematite ranging from soft, pulverulent bright-red material to hard, dense dark-blue iron oxide. More or less specularite is present. The association of the iron ore with beds of chert having "curly" or contorted laminations is of significance in connection with the origin of the ore. No limestone was noted anywhere at this horizon, and no oolitic or granular material was noted in the ore that might indicate original deposition as a ferruginous sediment. Much of the ore, however, shows traces of a contorted banding similar to that of the associated chert, a feature which strongly suggests that it originated through replacement of the banded rock by iron compounds.

As the Mescal rocks contain much limestone in other parts of Arizona it may be that they were originally calcarcous here and were replaced by solutions carrying both silica and iron. The ore bed contains also more or less chert partly replaced by iron oxide, and in some places the banded chert contains little or no iron oxide. The banded chert superficially resembles the remains of an algal growth which perhaps existed in the form of a reef in the Cambrian (?) sea.

The exposed thickness of the ore bed ranges, according to 16 observations in the Bear Spring Canyon locality, from 3 or 4 feet to about 21 feet, but the measurements available are not sufficient to afford a reliable general average. The bed is probably 10 to 20 feet thick on most of the Alsace-Lorraine claims. In the Chediski Mountain locality the thickness measured between 3 and 15 feet at 15 different places.

The best ore ranges from 50 to 65 per cent in metallic iron, 4.5 to 26.5 per cent in silica, and 0.12 to 0.40 per cent in phosphorus, but there is much ferruginous siliceous material that does not carry enough iron to warrant its classification as an ore. Ferruginous material that has been formed by replacement of a siliceous bed such as this is very likely to be irregular or "spotty" in composition.

If the ore has been deposited through replacement of a bed of Mescal limestone the question arises as to the source of the ironbearing solutions. Igneous rocks are naturally thought of at first 
in this connection. At Chediski Mountain (fig. 9) no igneous rocks are in evidence, but near Bear Spring Canyon (figs. 7 and 8) a large mass of diabase lies within about 200 feet below the ore bed, though nowhere observed to be in contact with the ore. There may be some significance in the fact that the ore near Bear Spring Canyon was found to be richest in iron at localities 2, 6, and 11 (fig. 7), which are near faults. A fault that follows Canyon Creek at the foot of Chediski Mountain may have given access to the Mescal limestone by iron-bearing waters coming from a buried mass of diabase. The geologic map of Arizona shows that larger areas of diabase occur a few miles west and south of the Bear Spring Canyon area.

\section{DEPOSITS NEAR BEAR SPRING CANYON}

OCCURRENCE AND CHARACTER

The deposits of iron ore along Canyon Creek near Bear Spring Canyon are the most valuable in this region. Figure 7 indicates their distribution and the relation of the iron-bearing area to the west boundary of the Fort Apache Indian Reservation. The evidences of ore are described below, beginning at locality $\hat{1}$ (fig. 7 ) and extending on the east side of Canyon Creek up the face of Swamp Creek Mountain toward the northeast as far as observed and then on the west side of Canyon Creek.

At locality 1, on the east bank of Canyon Creek about 2,500 feet north of The Pyramids, a ledge of iron ore is exposed near creek level. The beds stand nearly vertical or dip steeply toward the south. The material is more or less broken and is jointed in northwesterly and northeasterly directions to such an extent as to confuse the determination of the true strike. The mass is partly covered by soil, but fragments of ore show across a space of 25 feet or more. Some of the ore is good-quality hematite, but there is much unreplaced silica in the form of brecciated chert and quartzite within the mass, and the ore grades into quartzite on the borders of the ledge. This is apparently the locality where the ore bed crosses Canyon Creek. No ore shows in the creek, but if this outcrop is projected across the creek to locality 7 , on the west bank, where it is prospected, the strike would be about $\mathrm{N} .63^{\circ} \mathrm{W}$., which corresponds with the strike of quartzite ledges that cross the creek a short distance to the south. A few hundred feet northeastward up the mountain side, at an altitude of 100 feet or more above Canyon Creek, the iron-ore bed shows in a few massive outcrops of good-quality ore having a total thickness of 15 feet or more. The iron oxide appears to have replaced contorted banded chert, into which it grades above. 

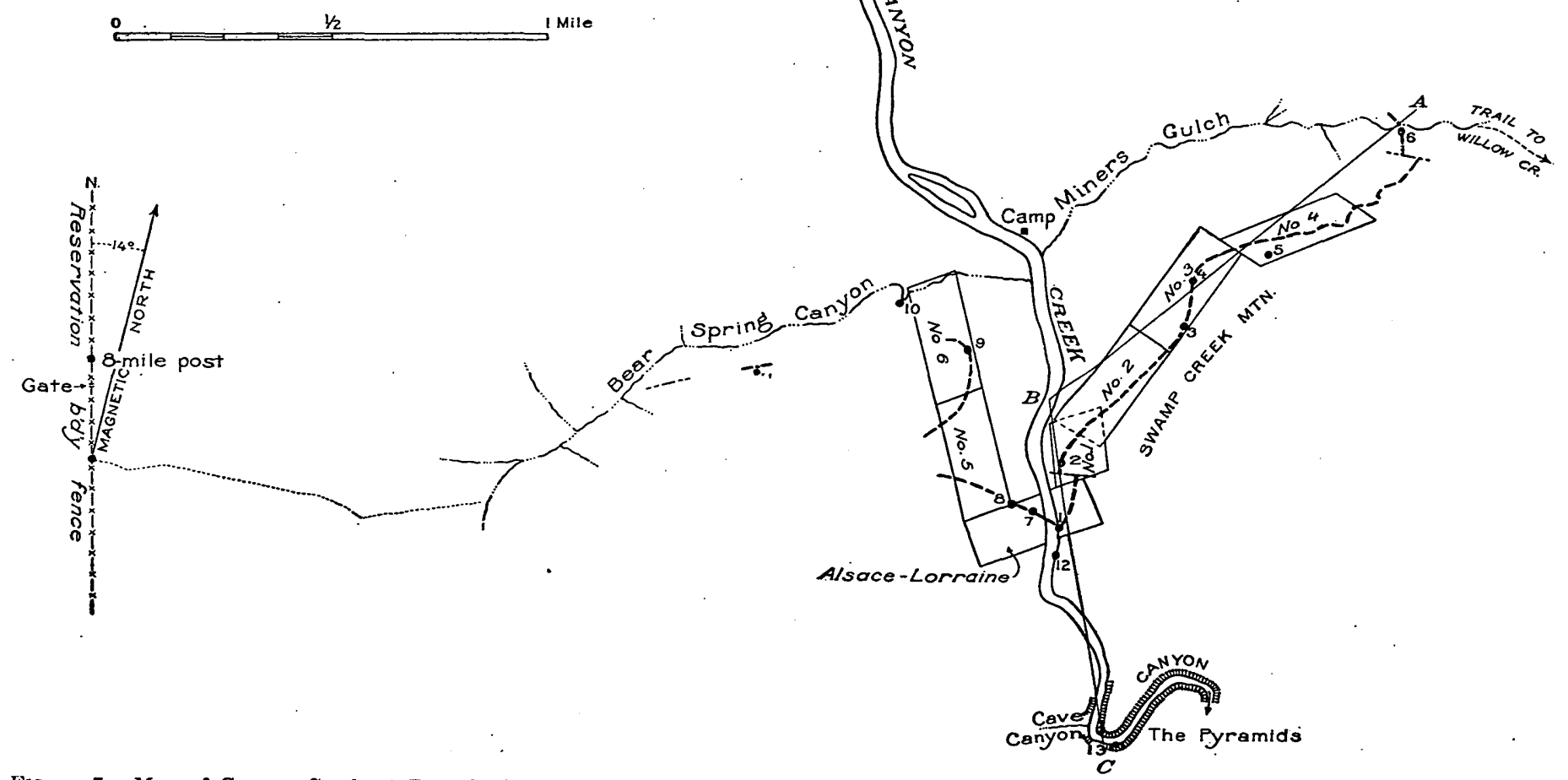


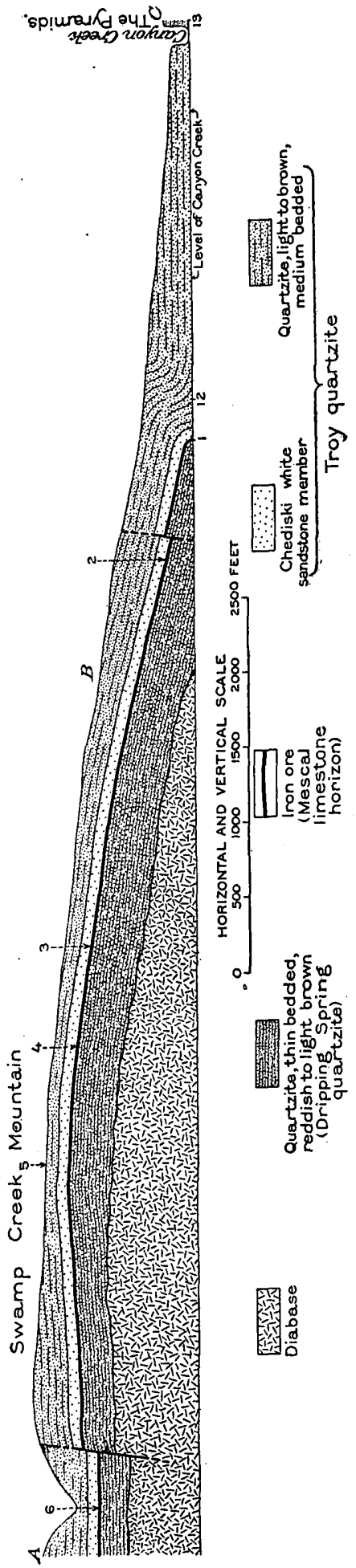

The beds here dip about $15^{\circ} \mathrm{S}$., but within 100 to 200 feet northeast of this outcrop they are dropped 50 or 60 feet by an east-west fault, beyond which they resume their upward tilt along the northwest face of Swamp Creek Mountain. A short distance north of the eastwest fault the iron-ore bed is well exposed in a prospect cut and also on the steep mountain side, at locality 2. (See fig. 7 and pl. 17, A.)

The prospect at locality 2 , which is about 140 feet above Canyon Creek, is perhaps the most impressive showing of iron ore in this vicinity. The ore beds show a total thickness of 21 feet 3 inches and dip about $16^{\circ} \mathrm{S} .15^{\circ}-20^{\circ} \mathrm{W}$. The ore throughout shows evidence of having been formed by replacement of banded chert, as there are all stages from slightly ferruginous chert to nearly pure hematite which still shows the original banded structure. In places the chert has been brecciated, and the cementing material is iron oxide. The iron oxide is mostly red hematite of medium hardness, but there are layers of hard blue hematite and vugs lined with minute bright crystals of specularite. The ore is considerably fractured and slickensided, even though in massive beds, and good hand specimens of it are difficult to prepare because of the tendency to break along the fractures. The ore at this prospect was sampled by B. W. Dyer in three parts, as indicated in the analyses below, which show a good grade of iron ore: 
Analyses of iron ore from Fort Apache Indian Reservation on Canyon Creele, locality 2

[J. G. Fairchild, analyst]

\begin{tabular}{|c|c|c|c|c|c|c|c|}
\hline Portion sampled & $\mathrm{Fe}$ & $\mathbf{P}$ & $\mathrm{SiO}_{2}$ & $\mathrm{CaO}$ & $\mathrm{MgO}$ & $\mathrm{TiO}_{2}$ & $\mathrm{~s}$ \\
\hline Upper 8 feet 6 inches. & 55.70 & 0.40 & 14.68 & & & & \\
\hline $\begin{array}{l}\text { Intermediate } 7 \text { feet } 9 \text { inches.......... } \\
\text { Bottom } 5 \text { feet }\end{array}$ & $\begin{array}{l}45.60 \\
59.15\end{array}$ & .24 & $\begin{array}{l}26.52 \\
12.66\end{array}$ & & & & \\
\hline Composite of these beds..... & 53.48 & .29 & 17.95 & $0.60^{-}$ & Tr. ? & 0.10 & 0.07 \\
\hline
\end{tabular}

By difference there is left for $\mathrm{Al}_{2} \mathrm{O}_{3}, \mathrm{~K}_{2} \mathrm{O}$, and $\mathrm{N}_{2} \mathrm{O}, 3.38$ per cent.

At this prospect there was a location monument containing a notice to the effect that H. S. Colcord had located "Canyon Creek No. 2 claim." The description was confused with reference to the actual boundaries of the claim, but the intent probably was to include the outcrop of the iron-ore bed for a distance of 1,500 feet along its strike on Swamp Creek Mountain, and the claim is evidently a relocation on No. 1 of the Alsace-Lorraine group.

The outcrop of the ore bed here is on a steep face of the mountain, as indicated in Plate 17, $A$, which had to be taken from the limb of a tree in order to get any distance in front of the object. A large block of good grade hard dark hematite, $21 / 2$ by 3 by 3 feet, lies on the left bank of Canyon Creek below this prospect.

The outcrop of the ore bed continues to rise northeastward along the face of Swamp Creek Mountain but is covered by talus of quartzite in most places. At locality 3, about 2,200 feet northnortheast of locality 2 , a red ledge of iron ore, conspicuous from Canyon Creek near the mouth of Miners Gulch, crops out on the steep face of the mountain, about five-sixths of the way to the top. The base of the ledge is about 665 feet above the creek. This ore bed is about 20 feet thick; the bottom 5 feet appears to be of the best grade, but all of it is partly siliceous. The Chediski white sandstone member lies just above the iron-ore bed.

At locality 4, about 600 feet north of locality 3 and 760 feet above Canyon Creek, a prospect cut 30 feet long, 5 feet wide, and 5 feet high shows a thickness of about 8 feet of good iron ore. (See pl. 17, B.) A discovery monument indicating that this is on AlsaceLorraine claim No. 3 stands near here. A partial analysis by J. G. Fairchild of ore from this prospect pit, sampled by B. W. Dyer, shows 54.2 per cent of iron, 0.12 per cent of phosphorus, and 22.42 per cent of silica.

A thin bed of cherty iron ore of no value on the outcrop was noted on the mountain side about 50 feet lower than the bed described above. It could not be traced for more than 300 feet.

At locality 5, about 1,000 feet northeast of locality 4, was found a United States Land Office monument pertaining to survey No. 3711, of the Alsace-Lorraine group of claims. This monument stands 
near the highest level of the escarpment of Swamp Creek Mountain, overlooking Miners Gulch and the Canyon Creek Valley and is about 965 feet above Canyon Creek. The iron-ore bed crops out about 150 feet below this level.

Between locality 5 and the Canyon Creek-Grasshopper trail in Miners Gulch the trace of the ore bed is sinuous around the heads of several steep gullies that descend northwestward into the gulch, and for most of the distance the outcrop is covered by talus of quartzite. At several points, however, the ore bed was recognized, and at one of these, about 1,000 feet south of Miners Gulch, 4 or 5 feet of rich ore was exposed. The ore bed is faulted downward to the north, possibly 100 feet, at a point just south of Miners Gulch, and beyond the fault the bed rises toward the northeast.

About 100 feet south of the trail in Miners Gulch, near locality 6, about 615 feet above Canyon Creek, an outcrop of the ore bed 8 feet thick was sampled by B. W. Dyer and analyzed by J. G. Fairchild with the following results: Iron, 65.05 per cent; phosphorus, 0.15 per cent; silica, 4.46 per cent. This is the highest-grade ore noted in place during this investigation.

In Miners Gulch the ore bed is not well exposed where the trail crosses the iron-bearing horizon, but there is much ferruginous débris at and just below this horizon, and large boulders of the more resistant ore from the bed are strewn well down the gulch toward Canyon Creek. North of Miners Gulch the ore bed thins and becomes very lean and cherty. Ferruginous material occurs north of the gulch at two horizons, one of them corresponding to the horizon of the sample obtained near locality 6 and the other about 60 feet higher, or just below the white sandstone bed. At the higher level the ore is only 3 to 4 feet thick and of a cherty character. As no good showings of ore were found northeast of these exposures and as the Alsace-Lorraine claims do not extend to the northeast quite as far as Miners Gulch, the traverse was not carried farther in this direction.

On the west side of Canyon Creek there is less evidence of iron ore. At locality 7, a few feet above creek level, there is a prospect pit in bouldery masses of iron ore of good quality. The thickness was not determinable, as the material was more or less covered by soil and vegetation, but is probably at least 20 feet. The beds are tilted steeply, as in the exposure at locality 1 , on the east side of the creek about 600 feet toward the southeast. About 250 feet westnorthwest of this prospect is a monument of loose stones and a block of diabase bearing the inscription $\begin{array}{r}2 \mathrm{AL} 5 \\ 3711\end{array}$, signifying that it is corner 2 of the Alsace-Lorraine claim 5 of the United States Land Office survey 3711. This monument stands on a terrace about 35 
feet higher than Canyon Creek and is indicated as locality 8 on Figure 7. On the plat of survey 3711 the outcrop of the ore bed, or "vein," is shown a few hundred feet west of this point as extending $\mathrm{N} .12^{\circ} 5^{\prime} \mathrm{W}$. through the middle of claims 5 and 6 . The topographic and structural relations here, however, preclude such regularity in the outcrop, and it is probable that the actual trace of the ore bed swings to the west up a hollow and follows to some extent the contour of the mountain side while rising toward the north. The ore bed is not exposed on the terrace, which has been built of quartzite débris washed down the hollow, nor does it show anywhere on the steep, quartzite talus-covered mountain side except at locality 9 , near the east border of claim 6 , about 1,950 feet $N$. $13^{\circ} \mathrm{W}$. of locality 8 , where there is a good natural outcrop and prospect about 460 feet above Canyon Creek, on the steep east face of the mountain about 175 feet below the top. The top of this mountain is capped by massive quartzite of the Troy formation, and the Chediski white sandstone member crops out about 155 feet below the summit and dips at moderate but varying degrees toward the west. The base of this white sandstone is somewhat brecciated and, together with a cherty bed below, is ferruginous in places. About 20 feet lower the actual bed of iron ore shows strongly on the mountain side. Sighting across to Swamp Creek Mountain on the east side of Canyon Creek shows that at the same distance north of the discovery outcrop (locality 1) the ore bed is at a slightly lower altitude on the west side than on the east side of the creek, and the general strike of the ore bed appears to be about $\mathrm{N} .77^{\circ} \mathrm{W}$. Prospecting has also been done on the north side of the knob and discloses that the bed of ore is about 20 feet thick. The ore appears to be of fairly good quality, although more or less siliceous in places. A sample cut by B. W. Dyer and analyzed by J. G. Fairchild showed 50.73 per cent of iron, 0.25 per cent of phosphorus, and 22.42 per cent of silica.

The projection of Alsace-Lorraine claim 6 on the field map made during this investigation shows that the claim extends northward to Bear Spring Canyon, but the topography is such that the ironore bed has been removed by erosion north of locality 9 . No other outcrops of iron ore were seen on these claims, but in a traverse from Canyon Creek to the west boundary of the Fort Apache Indian Reservation a bed of ferruginous quartzite and a location monument with no identification marks or papers were noted on the south slope of Bear Spring Canyon at locality 11, about 2,100 feet west of locality 9 . Only 2 or 3 feet of ore was exposed here, not necessarily the entire thickness of the bed, and some high-grade float fragments of ore were observed on the slope toward the canyon. The altitude of 
this ferruginous material is about 300 feet higher than Canyon Creek, or about 160 feet lower than the ore at locality 9, but it may very well be at the same stratigraphic horizon on account of the westward dip of the beds at locality 9 .

The unevenness in the surface of the diabase is well illustrated in Bear Spring Canyon. Below locality 11 the diabase rises to a height of about 240 feet above Canyon Creek, but farther northeast a narrow gorge in Bear Spring Canyon at locality 10 is cut in quartzite at a level 125 feet lower. The diabase below locality 11 is thus only about 60 feet below the horizon of the iron ore.

The following additional analyses are included for the sake of comparison :

Analyses of iron ore from Alsace-Lorraine claims

[Data supplied by Colorado Fuel \& Iron Co.]

\begin{tabular}{|c|c|c|c|c|c|}
\hline & & & $\mathrm{Fe}$ & $\mathbf{P}$ & $\mathrm{SiO}_{3}$ \\
\hline \multicolumn{3}{|l|}{ Sampled by T. N. Jerrard } & & & \\
\hline \multicolumn{3}{|c|}{$\begin{array}{l}\text { Alsace-Lorraine claim, bottom } 6 \text { feet, assessment pit } \\
\text { Alsace-Lorraine claim } 2 \text {, } 13 \text { feet of ore, assessment pit } \\
\text { Alsace-Lorraine claim, outcrop on east side of Canyon Creek } \\
\text { Alsace-Lorraine claim 4, ledge } 50 \text { feet north of assessment pit } \\
\text { Alsace-Lorraine claim 1, top } 5 \text { feet of ore in assessment pit. } \\
\text { Alsace-Lorraine claim 1, ore } 15 \text { feet thick in cut } \\
\text { Alsace-Lorraine claim 2, bottom } 5 \text { feet in cut... } \\
\text { Alsace-Lorraine claim 3, cut across ore. }\end{array}$} & $\begin{array}{l}45.5 \\
56.0 \\
59.5 \\
66.7 \\
46.7 \\
56.8 \\
43.6 \\
51.8\end{array}$ & $\begin{array}{r}0.161 \\
.200 \\
.234 \\
.220 \\
.376 \\
.284 \\
.295 \\
.152\end{array}$ & $\begin{array}{r}29.00 \\
16.55 \\
11.00 \\
2.14 \\
27.72 \\
12.40 \\
31.25 \\
19.10\end{array}$ \\
\hline . & $\mathrm{Fe}$ & $\mathbf{P}$ & $\mathrm{SiO}_{2}$ & $\mathrm{CaO}$ & $\mathrm{MgO}$ \\
\hline \multicolumn{6}{|l|}{ Sampled by F. U. Nelson, 1920} \\
\hline $\begin{array}{l}\text { Alsace-Lorraine claim 1 } \\
\text { Alsace-Lorraine claim } 2 \\
\text { Alsace-Lorraine claim, } \\
\text { Alsace-Lorraine claim } 8 \\
\text { Alsace-Lorraine claim, east side of Canyon Creek } \\
\text { Alsace-Lorraine claim, west side of Canyon Creek }\end{array}$ & $\begin{array}{l}60.0 \\
57.3 \\
60.3 \\
52.2 \\
66.5 \\
64.6\end{array}$ & $\begin{array}{l}0.183 \\
.281 \\
.310 \\
.181 \\
.199 \\
.903\end{array}$ & \begin{tabular}{r|}
12.03 \\
13.63 \\
10.52 \\
21.46 \\
3.42 \\
.302
\end{tabular} & $\begin{array}{r}0.75 \\
.66 \\
.68 \\
.60 \\
.18\end{array}$ & $\begin{array}{l}\text { Trace. } \\
\text { Trace. } \\
\text { Trace. } \\
\text { Trace. } \\
\text { Trace. }\end{array}$ \\
\hline
\end{tabular}

PROBABLE EXTENT AND TONNAGE OF ORE

In order to make a satisfactory estimate of recoverable iron ore in a bedded deposit certain basic facts must be known, the most essential of which are length of outcrop, average thickness of bed at outcrop, minimum thickness to which the bed may be mined, maximum distance from outcrop to which the bed may be mined, average percentage of metallic iron in the ore, specific gravity from which the number of cubic feet per long ton of ore may be derived, and percentage of ore that may be recovered under the necessary conditions of mining. 
The most definite quantitative facts known concerning the ironore bed in this part of the Canyon Creek district are its extent of outcrop, its observed thicknesses at 9 or 10 places, and its chemical composition at several of these places. Nothing is known concerning the extent of the ore bed below cover, as no drilling or other prospecting has been done beyond the outcrop.

Figure 7 indicates that the length of outcrop of the ore bed, beginning at locality 9 and extending southeastward across Canyon Creek to locality 1 , thence northeastward to a place a short distance beyond Miners Gulch, near locality 6, approximates 9,000 feet. The average thickness of the bed where measured is 15 feet, but there are many places where the outcrop is covered by talus, so that the actual thickness is unknown and may be less than where observed, and the nature of the bed indicates the probability that mining might encounter many barren areas which would contribute to making the average thickness less than 15 feet. The weighted average specific gravity of the specimens analyzed by the United States Geological Survey is 3.953 , which is equivalent to approximately 9 cubic feet per long ton. These analyses (pp. 63,64) show an average of nearly 55 per cent of metallic iron in the ore, and the additional analyses given on page 65 show an average of 56.3 per cent, but the caution. should be expressed here that there is in the bed much ore that appears to contain less than 50 per cent of iron.

In view of the paucity of known data on which to base estimates of ore tonnage it is obvious that much will have to be assumed, and that such estimates as may be attempted will be accurate only in so far as the assumed data are correct-conditions which leave room for great uncertainty as to the results. The unknown factor that would have the greatest effect on the estimates is the distance to which the bed of ore extends in minable thickness and quality into the mountains east and west of Canyon Creek and southward below the creek south of the point where a sharp fold brings it to the surface at localities 1 and 7. The boundaries of the Alsace-Lorraine claims have little to do with the problem of estimation of the iron-ore reserves in the area, as these claims have no extralateral rights. The problem is to determine how far the bed might be mined, if all other conditions, such as transportation facilities, labor supply, and markets, were favorable, and this problem can be solved to a certainty only by thorough drilling supplemented by the excavation of a few tunnels. 
As the outcrops along Canyon Creek suggest an anticline plunging toward the south the ore bed, if projected eastward or southeastward, should crop out on the east side of Swamp Creek Mountain in the canyon of Swamp Creek, unless beneath the mountain the dip becomes much steeper or a fault intervenes to drop the ore abruptly. The trail from the crest of Swamp Creek Mountain to Willow Creek leads mostly over limestone that is normally several hundred feet above the ore horizon, so that no outcrop of ore was seen in this direction. Time was not available to make a traverse down the canyon of Swamp Creek to ascertain whether the iron ore appears in it, but John Slayton, a cow-puncher who is familiar with this locality, stated that he had observed no iron ore along Swamp Creek.

If the average thickness of the bed is taken as 10 feet, the quantity of iron ore that may be expected to occur in a strip 1,500 feet wide along an outcrop 9,000 feet long, upon the assumption of a volume of 9 cubic feet to the long ton, is 15,000,000 long tons. From this tonnage must be deducted the ore that would have to be left as pillars and as roof in mining, together with an allowance for possible barren and lean places in the ore bed. If these deductions amounted to $331 / 3$ per cent, they would leave $10,000,000$ long tons as a conservative estimate of the quantity of recoverable ore in an area of the above-stated dimensions along Canyon Creek in the vicinity of Bear Spring Canyon.

It is not known to what distance from the outcrop the ore extends or is minable. If the iron-ore beds had been formed by the original deposition of ferruginous sediments, such as those of the Clinton or Red Mountain ores of the Appalachian region are believed to have been, it would be safe to assume without drilling that the ore extends underground from the outcrop much more than 1,500 feet, provided the dip and other structural conditions are favorable, but deposits of iron oxide that have resulted from the replacement of calcareous and siliceous beds like the original limestone and chert in this region can not be depended upon to prove constant over great distances. There is, however, evidence that the replacement to varying degrees by iron oxide of beds at the horizon of the Mescal limestone has extended along the valley of Canyon Creek for several miles, and this gives encouragement to the belief that at the locality of greatest observed richness the ore deposit may prove to be of wider extent than is assumed above, and also that at other places not visited on this inspection the ferruginous replacement may be found to have extended for considerable distances along this horizon in the vicinity of the diabase laccoliths. If favorable conditions of ore and structure are present, it should be possible to mine farther than 1,500 feet from the outcrop in the Bear Spring locality on Canyon Creek. 
By H. W. Dres

Prospecting and mining.-The iron-ore deposit that crops out on both sides of Canyon Creek just south of Bear Spring Canyon and Miners Gulch has both favorable and unfavorable natural mining conditions. Before any mining could be attempted here it would be necessary to do core drilling. It is estimated that there is a least $10,000,000$ tons of minable ore in sight. In this estimate no ore more than 1,500 feet from the outcrop or below the level of Canyon Creek was considered. The area east of Alsace-Lorraine claims 1, 2, 3 , and 4 should be drilled to locate the eastern boundary of the minable ore. The first holes would in all probability be drilled near Swamp Creek, which lies east of Swamp Creek Mountain but is not shown on Figure 7. It is believed that holes from 500 to 1,000 feet. in depth would be required to test the deposit.

From the outcrops in Miners Gulch and Bear Spring Canyon the ore deposit dips generally between $15^{\circ}$ and $20^{\circ} \mathrm{S}$. until it reaches the Alsace-Lorraine claim. At this point the ore takes a sudden plunge and dips $60^{\circ}-75^{\circ} \mathrm{S}$. A short distance south of the abrupt change in dip the strata become nearly horizontal and continue thus to and beyond The Pyramids. Drilling south of the Alsace-Lorraine claim. should be done to ascertain the nature and depth of the deposit in this area.

The deposit appears to be a replacement body in which the iron has replaced a cherty bed. There is no well-defined roof or floor, and as all the ore will be mined by underground methods an uneven roof and floor will add slight complications.

Transportation.-As the cleposit is remote from transportation facilities a large investment would be necessary for its development. A logging road has been constructed from Snowflake, on the Apache Railway, to Standard, in the northeast corner of T. 10 N., R. 19 E., a distance of about 20 miles. The Apache Railway connects with the Atchison, Topeka \& Santa Fe Railway at Holbrook. The airline distance from Standard to the iron-ore deposit is about 26 miles, but a feasible route for a railroad between these places would probably be about 40 miles in length. Most of this route would be through the mountains, and it is believed that the cost of construction would be not less than $\$ 80,000$ a mile.

Water supply.-The iron-ore deposit lies on both sides of Canyon Creek. At the time of the investigation, in June, 1929, this stream was flowing about 20 second-feet of water. The creek was then at the low summer stage; however, in the winter the flow may be slightly less, but during the melting of snows and during heavy rains it is much greater. The amount of water in Canyon Creek 
is ample for domestic purposes and for the mining of a deposit of this size.

Fuel.-The nearest fuel other than wood for developing power is at Gallup, N. Mex., where a good supply of coal is available. The distance from Gallup to the iron-ore deposit would be about 200 miles by railroad. It is probable that fuel oil could be obtained from California at a reasonable price. The distance to Los Angeles from Holbrook, Ariz., is 640 miles. It is not believed that hydroelectric power could be economically developed in the vicinity of the deposit. The nearest supply of coke is at Trinidad, Colo.

(A report by F. U. Nelson to the Colorado Fuel \& Iron Co. states that there are coal deposits at Pineville, 35 miles northeast of the iron claims. He states that the Government reports as follows: "Prospect pits show two beds of coal 10 to 15 feet apart. The upper bed reaches a maximum thickness of about 12 feet at the Merwin prospect, in the NE. $1 / 4$ NE. $1 / 4$ sec. 36, T. 11 N., R. 18 E. Of this 12 feet only about half can be called coal, and even this half is very dirty. The lower bed is thinner but of much better quality; it shows from 2 to 3 feet of very good subbituminous coal."-E. F. B.)

Timber.-The area from the end of the present logging railroad to Canyon Creek is well wooded with yellow pine of good quality. This would furnish, at a low cost, timber for construction and mine purposes.

Town site.-A fairly good and convenient town site exists along Canyon Creek in the vicinity of Miners Gulch and Bear Spring Canyon. Here there are gently rising terraces covered with cottonwood and oak trees, and the area is large enough to allow the building of a comfortable village.

\section{DEPOSITS NEAR WIILOW CREEK}

The bed of iron ore in the Mescal formation crops out on the northeast (left) side of Canyon Creek 2,000 to 3,200 feet upstream from the mouth of Willow Creek and also high on the side of Chediski Mountain on the right side of Canyon Creek opposite and below the mouth of Willow Creek. (See fig. 9.) On the northeast side of Canyon Creek the ore bed extends from the level of the creek to about 30 feet above it. Some lode claims were located in this vicinity by H. S. Colcord, of Young, Ariz., and others, in August, 1926. Near the monument of "Cheitski No. 2 " claim (locality 14, fig. 9) is an outcrop of siliceous ferruginous rock in the bank of the creek where assessment work has been done by stripping off the cover of soil and blasting openings. A total thickness of about 9 feet of very low grade ore is visible. About 200 feet farther up the creek is a 7-foot cliff of ferruginous laminated quartzite in 
which about 1 foot 3 inches of good hematite is visible. A prospect pit (locality 15, fig. 9) 960 feet upstream from the monument at claim 2 shows a few feet of iron ore of varying quality. An irrigation ditch along the north side of Canyon Creek here supplies water to a tract of land in the valley known as the Chediski Indian Farms. A pit (locality 16) about 3,025 feet upstream from Willow Creek, in the hillside about 25 feet above the irrigation ditch, shows 6 feet of good hematite grading below and above into siliceous rock. The ore is at a much lower level on the northeast than on the southwest

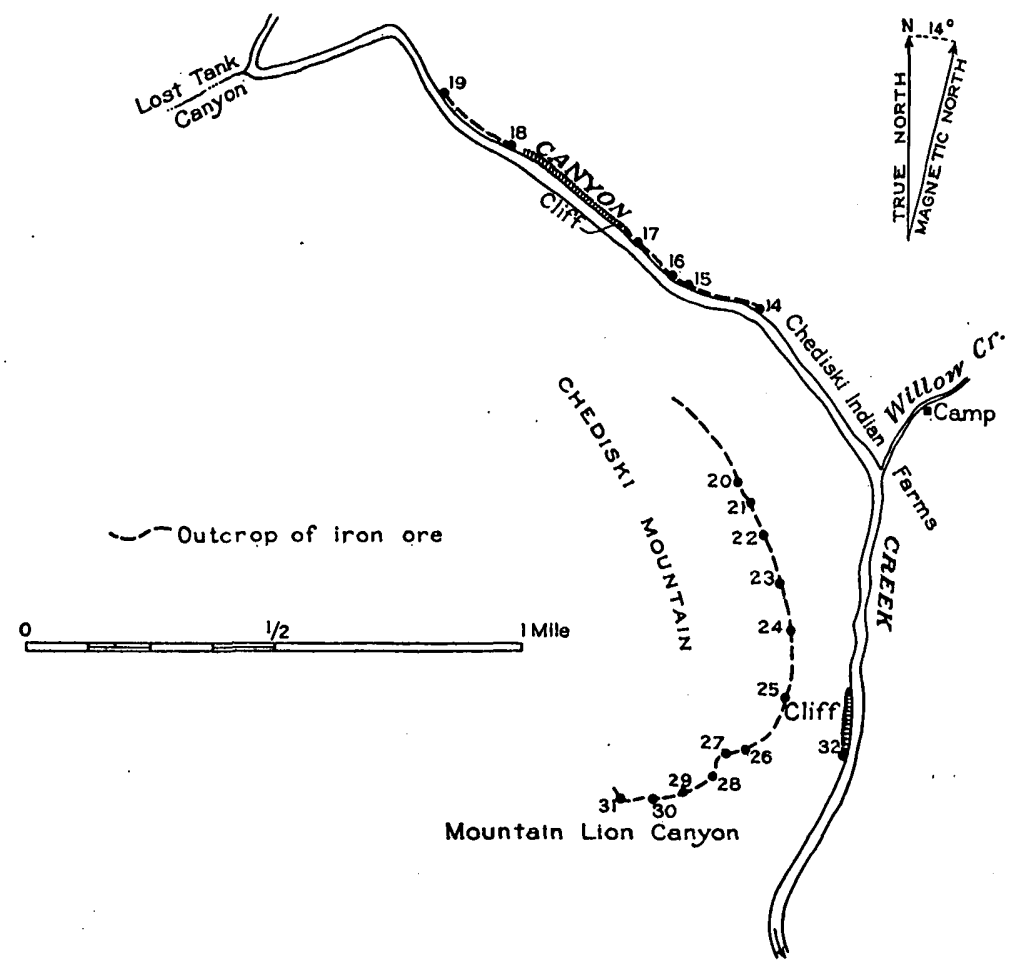

Figurn 9.-Map of Canyon Creek at Willow Creek, showing outcrop of iron-ore bed. By E. F. Burchard and B. W. Dyer. Based on paced traverse

side of Canyon Creek in this vicinity, having been dislocated by a fault that probably extends northwestward somewhere near the southwest bank of the creek. The general dip of the beds is low toward the west-northwest here, and about 3,500 feet upstream from Willow Creek the Chediski white sandstone member of the Troy quartzite, which lies above the ore bed, comes down to the level of Canyon Creek and forms the northeast wall of the creek for a distance of about 1,600 feet, in a series of picturesque cliffs (localities 17 and 18; see fig. 9 and pl. 14, $B$ ). At one place in this sandstone area a small ravine comes into the canyon from the north-northeast, and stones 
have been piled up in the form of a monument, which, however, contained no location notice at the time of visit. A few boulders of hard hematite, one of them measuring 8 by 15 inches, were scattered about here. This ravine was followed for a short distance and several small rounded boulders of hard hematite were noted, but their source was not found. Inasmuch as the ravine is cut in the Chediski white sandstone member, the hematite may be derived from a thin bed somewhere above this sandstone. Where the white sandstone rises toward the northwest beds of ferruginous quartzite and conglomerate are exposed below it, and the Black Iron and Chediski claims have been located (locality 19, fig. 9). No iron ore of commercial grade was seen here or farther upstream, but here and there fragments or boulders of ore were noted at the base of the cliff or in the stream bed as far as the mouth of Lost Tank Canyon, where the traverse was terminated in this direction.

On the right-hand side of Canyon Creek the iron-ore bed is on the northeast face of Chediski Mountain, generally 300 to more than 700 feet above the creek. Claims have been located on the mountain opposite and below the mouth of Willow Creek, as indicated by monuments erected on quartzite ledges that are ferruginous in places. One of these monuments (locality 20, fig. 9), about 335 feet above Canyon Creek, is nearly west of the mouth of Willow Creek. Another monument, at locality 21, bears S. $75^{\circ} \mathrm{W}$. from the mouth of Willow Creek and is 450 feet above Canyon Creek. These monuments contained no claim papers at the time of visit. Another point a little farther south on the ledge where ferruginous material was noted (locality 22) is 515 feet above the creek. This ledge is about 100 feet below the prominent white Chediski sandstone member on the face of Chediski Mountain (pl. 14, $A$ ) and may not represent the best ore bed, as in other places, notably on the claims near Bear Spring Canyon, the richest iron-bearing material is generally close below the white sandstone. Such ferruginous material as was noted here on Chediski Mountain (localities 20 to 22) would probably not carry more than 10 to 15 per cent of iron. An assessment pit (locality 23) with a monument containing no claim papers was noted at an altitude of about 550 feet above Canyon Creek, bearing S. $44^{\circ} \mathrm{W}$. from the mouth of Willow Creek. Here a ledge of quartzite has been more or less replaced by iron. It is rich in small spots but in many areas is not replaced at all, and the whole would probably not average 30 per cent of iron. The pit, which is about 6 feet deep, shows about 1 foot of ferruginous material above a layer that is sparsely replaced by iron oxide and some very ferruginous shaly quartzite near the top. Float pieces of rich reddish hematite, containing fine scales of specularite, are strewn along this hori- 
zon and indicate that there is some good ore in the ledge. The orebearing ledge rises gently toward the southeast here, and the next pit observed (locality 24) has been made at an altitude about 625 feet above Canyon Creek. A cut here 4 to 6 feet wide, 7 feet high, and 10 feet long discloses dark-red ferruginous quartzite that breaks with a hackly fracture and is somewhat slickensided. This material is somewhat uniformly replaced by iron oxide and is a moderately fair grade iron ore. The total thickness is about 6 feet, and it lies about 10 feet below a ledge of light-colored sandstone. A location monument has been built near and a few feet higher than this pit on a ledge of brecciated cherty rock with contorted banding. The monument contained no claim papers when seen. The outcrop of iron-bearing rock may be traced toward the south around to a point where the mountain slope faces east (locality 25 ), and a prospect bearing S. $24^{\circ} \mathrm{W}$. from the mouth of Willow Creek has been made at an altitude of about 660 feet above Canyon Creek. A monument here contains a notice of mining location of lode claim Iron Mountain No. 6, by H. S. Colcord and others, dated August 29, 1926. Another notice dated September 8, 1921, was also found here covering a claim of the same name and dimensions by Wesley Goswick and A. B. Custis. This prospect cut is about 10 feet long, 4 feet wide, and 8 feet deep. The ore disclosed appears to be a red hematite of good grade containing some specularite. It shows fractures and slickensides and some small cavities, and the texture indicates replacement of chert, remnants of which may be seen in the ledge. This locality is a little south of an east-west line passing through the south end of a prominent cliff of quartzite on the top of Chediski Mountain and is probably 400 feet lower than the highest point of that cliff. The iron-bearing ledge may be traced 500 to 600 feet farther around the face of Chediski Mountain to a steep southward-facing slope overlooking Mountain Lion Canyon, a narrow gorge that opens into Canyon Creek from the west. The ore ledge is mostly only a few feet thick, but a locally thicker place was observed on which was a monument carrying a notice of claim by H. S. Colcord, called "Iron Mountain No. 6," dated August 28, 1926, that may mark the south end of this claim (locality 26). At this place, which is about 675 feet above Canyon Creek, there is a thickness of about 15 feet, mostly of fair-grade ore, bared by erosion on the mountain slope. Westward around the contour of the mountain the iron-bearing outcrop is covered for 200 feet or more by a heavy talus of light-colored quartzite, but about 100 feet west of locality 26 is a monument containing notice of location of "Claim VII" by Wesley Goswick and A. B. Custis, dated September 8, 1921. About 200 feet west of locality 26 is a large natural exposure 
of iron ore (locality 27), 13 to 15 feet thick. The upper layers of this ledge contain considerable specularite in fine grains, and the beds might possibly average 40 per cent in iron through a thickness of 10 to 12 feet. Below the richer beds there is some unreplaced siliceous rock interlayed with ferruginous rock, and below this zone is fractured chert containing thin layers of hematite, which diminish in abundance downward. The iron-bearing beds appear to be the result of a replacement of chert having a contorted banding similar to that at the Bear Spring Canyon locality, and they grade upward into chert of this character. The dip of these beds is low toward the northwest, so that this exposure is practically on the strike with and at about the same altitude as that at locality 26. Just southwest of locality 27 the contour of Mountain Lion Canyon curves southward for a few hundred feet around the head of a gully, and in the eastward-facing portion is a prospect revealing a few feet of fair-grade iron ore on which a monument has been erected that contained a notice of "Iron Mountain claim No. 7," by H. S. Colcord, dated August 28, 1926 (locality 28). About 350 feet around the hill southwest from locality 28 , at about the same altitude, stands a monument for "Iron Mountain No. 8" (locality 29), also located by Colcord on the same date. The ledge appears to become more siliceous toward the southwest and shows only spots of rich iron oxide. About 300 feet southwest of locality 29 stands a location monument for "Iron Mountain No. 7 (?)" (the number was not clear), made by H. S. Colcord July 3, 1924 (locality 30), at an altitude a few feet higher than at localities 26 to 29 . The ore-bearing ledge consists of about 12 feet of rather siliceous iron oxide. The last point noted toward the southwest on this traverse faces southwest on the steep canyon, a few hundred feet west of locality 30 . Here a small prospect cut shows a few feet of contorted banded chert more or less replaced by hematite that is rich only in spots. This point (locality 31) is about 700 feet (barometric altitude) above Canyon Creek.

On the west bank of Canyon Creek about 2,350 feet below the mouth of Willow Creek is exposed a large mass of white clay and sand below which is a ferruginous clay that contains enough iron in places to give it the appearance of a low-grade soft iron ore. This block of material is nearly 700 feet long, and at its south end just above creek level (locality 32) a red ledge of ferruginous sandy clay has been prospected by H. S. Colcord, it is reported, but the former monument has been washed away. The material in this whole block appears to have been much shattered and crushed and has been greatly disintegrated by weathering. It may represent a block of the Chediski white sandstone member and the underlying iron ore that has been brought down to a lower level by a landslide, or 
possibly by a fault, the white sandy clay having been produced by weathering of the sericitic sandstone.

From what was seen of the iron-bearing material on Chediski Mountain and along the northeast side of Canyon Creek between the mouth of Willow Creek and Lost Tank Canyon it does not appear probable that the ferruginous deposits in this vicinity can be considered as holding much promise for future commercial development. Such material as is of good grade occurs only locally along the outcrop, and much of the ledge is nearly barren of iron. No specimens were taken for analysis, because material that would be representative of the iron-bearing bed as a whole could hardly be called iron ore. Moreover, the nature of such ore as there is-probably formed by the replacement of limestone and chert-renders the distribution of rich iron oxide likely to be very irregular and spotty, with silica the predominating accessory mineral in most places.

\section{CONCLUSIONS}

The results of the brief surveys of a portion of the valley of Canyon Creek here recorded indicate that there is a bedded deposit of iron ore of good commercial grade near the mouth of Bear Spring Canyon. It is estimated that the quantity of minable ore reasonably to be expected in this locality will reach 10,000,000 long tons, but it will require prospecting by core drill to demonstrate this quantity with certainty, and there is a possibility that even more ore may be found. Consideration of the feasibility of mining and transporting the ore reveals no unusual difficulties, although it is recognized that the deposit possesses both favorable and unfavorable natural mining conditions. The economics of marketing or utilization of the ore have not been worked out. The nearest iron blast furnaces are at Pueblo, Colo., and Provo, Utah, but in time a furnace may be established near Los Angeles, Calif., to supply local steel plants, and that locality would have a slight advantage in the distance that the ore would have to be hauled. Small quantities of iron ore are used as flux in smelting ores of copper and other metals in the West and in open-hearth steel furnaces on the Pacific coast, but demands of this kind are not large enough to warrant the opening of a mine in this locality.

Reports on deposits of iron ore farther south in the valley of Canyon Creek, near Oak Creek and west of the boundary of the Fort Apache Indian Reservation near Gentry Creek, suggest that a broader study of the region with reference to this resource may reveal other deposits of interest. 



\section{INDEX}

Acknowledgments for aid Page

Alhajuela, Canal Zone, geologic maps _and cross section of area near...... pls. 5,6

(in pocket)

Alsace-Lorraine claims, Fort-Apache Indian Reservation, Ariz., analyses of iron ore from.

Apache group, formations of, in central Arizona

Artesian circulation, possibility of leakage of Madden Reservoir by 33-34

Azote Caballo River, Canal Zone, profile along ridge above.................... pl. 13

saddles on ridge above.

Blaine County, Idaho, metal production of, graph showing -

Bohio formation, general character of........ 17-18

limestone of, suitability of, for crushed stone............................. 39

possibility of leakage along openings in .. 31-32

Boise County, Idaho, metal production of, graph showing.

pl. 3

Burchard, Ernest F., Iron ore on Canyon Creek, Fort Apache Indian Reservation, Arizona.

Caimito (?) formation, compressive strength of sample of.

exposure of, on Rio Chagres

general character of

15

possibility of leakage along openings in .. 31-32

solution tests of specimens of ........... 24-25

suitability of, for supporting abutments of Madden Dam. . ................ 34-35

Canal Zone, map of, showing position of proposed Madden Reservoir.......... pl. 4

Canyon Creek, Ariz., at mouth of Miners Gulch, view of.

pl. 15

panorama from west side of. pl. 18

prospects in bed of iron ore on ............ pl. 17

section of rocks along .................. 56

Chediski Mountain, Ariz.; view of . ........... pl. 14

Chediski white sandstone member of Troy quartzite on Canyon Creek, Ariz., thickness of.............. 56

view of

Chert, banded, partly replaced by iron oxide, specimen of ....................... pl. 16

Colorado Fuel \& Iron Co., analyses of iron ore furnished by.................. 66

Copper, production of, in Idaho ............ 4

Culebra formation, general character of ...... 16-17 solution tests of specimens of ... . ......... 24-25

Custer County, Idaho, metal production of, graph showing.

pl. 3
Dripping Spring quartzite on Canyon Creek, Ariz., thickness of -............. 56

view of ..................................... pl 15

Dyer, B. W., Conditions affecting mining development in Fort Apache Indian Reservation, Ariz.......... 69-70

Emperador limestone, exposure of, on Rio Chagres................... pls. 9, 10 general character of ....................... 15-16 possibility of leakage along openings in .. 31-33 solution tests of specimens of............. 24-25

Fairchild, J. G., analyses of iron ore by ... 63,64,65 Fort Apache Indian Reservation, Ariz., geographic features of............... 53-55

geology of . . . . .

iron ore in .......... $51-75$

analyses of . . .................... $63,64,65,66$

Gatun (?) formation, compressive strength of sample of...................... 34 exposure of, in cliff above dam site 1..... pl. 7 general character of....................... 14-15 solution tests of specimens of . .......... 24-25 suitability of, for supporting abutments of Madden Dam ................. 34

Gatun Lake, Canal Zone, wave-cut terraces on ................................ 36-37

Gold, production of, in Idaho............. 2-3 graph showing........................... pl. 1

Idaho, gold production in, graph showing.... pl. 1 gold production in, review of ........... 2-3 metal mining in, history_of.............. 1-7

outlook for ........................ $7-9$ production of metals in, by counties..... 5-7 total metal production of, and production of metals other than gold in, graphs showing................ pl. 2

Idaho County, Idaho, metal production of, graph showing................... pl. 3

Iron-ore deposits on Fort A pache Indian Reservation, Ariz., character and

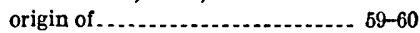

conclusions regarding distribution of ............................. 58-59 location and accessibility of............ 51-53 rocks associated with . .................. 58

Iron ore near Bear Spring Canyon, Ariz., conditions affecting mining development of .................... 69-70

occurrence and character of .............. 60-66 probable extent and tonnage of.......... 66-68 Iron ore near Willow Creek, Ariz., occurrence and character of ................ 70-75 
Lead, production of, in Idaho

Lemhi County, Idaho, metal production of, graph showing.

Madden Dam project, Canal Zone, character of dam sites on

construction materials for -38-43

diamond-drill holes on, records of . . . . ... 43-49

diamond drilling on, view of.............. pl. 12

pressure tests of wells on................. 26-28

previous investigations of .............. 12

rocks in vicinity of............... 13-14

tests of solubility of pieces of diamonddrill cores from

outfit used in

24-26

water table on, altitude of

pl. 11

20-22

seasonal variation in

Madden Reservoir, Canal Zone, geologic maps and cross sections of locality of proposed........ pls. 5, 6 (in pocket)

height of proposed dam at . ............. 37-38

map showing position of .................. pl.4

possibility of leakage from ............... 30-34

saddles on ridges surrounding ........... 35-37

site of, conclusions and recommendations regarding -..................... 40-42

structure of area included in and adjacent to . .................................. 18-19

suitability of rocks at, for supporting abutments of dam ................. 34-35

Martin (?) limestone, thickness of, on Canyon Creek, Ariz .........................

Mescal limestone on Canyon Creek, Ariz., thickness of,
Owyhee County, Idaho, metal production of, graph showing .................... pl. 3

Pyramids, The, on Canyon Creek, Ariz., view of ............................... pl. 16

Quebrada Madronal, Canal Zone, profile along crests of ridge above . ............. pl. 13

saddles on ridge above........... 35-36

Reeves, Frank, and Ross, Clyde P., A geologic study of the Madden Dam project, Alhajuela, Canal Zone... 11-49

Rio Chagres. Canal Zone, gravel and sand in 0 channel of, quality of, for use in concrete. . ............. 39-40

relation of water table on dike ridge to distance from............... 23

views on............................ pls. 8, 9, 10

Ross, Clyde P., A graphic history of metal mining in Idaho ............... 1-9

Reeves, Frank, and, A geologic study of the Madden Dam project, Alhajuela, Canal Zone.............. 11-49

Shoshone County, Idaho, total metal production of, graph showing............. pl. 2

Silver, production of, in Idaho................

Troy quartzite, on Canyon Creek, Ariz., thickness of ...................... 56

United States Bureau of Mines, analyses of iron ore by

Volcanic complex, suitability of rock of, for crushed stone 